\title{
The Characteristics and Quality of Egg from Commercial Laying Hens Fed with Garlic (Allium Sativum) Supplemented Ration
}

\author{
Jein Rinny Leke ${ }^{1}{ }^{*}$, Erwin Wantasen ${ }^{2}$, Florencia Sompie ${ }^{3}$, Femy Hadidjah Elly ${ }^{2}$ and Ratna Siahan ${ }^{4}$ \\ ${ }^{1}$ Department of Animal Production, Faculty of Animal Science, University of Sam Ratulangi, Manado, Indonesia \\ ${ }^{2}$ Department of Socio Economic, Faculty of Animal Science, Faculty of Animal Science, University of Sam Ratulangi, \\ Manado, Indonesia \\ ${ }^{3}$ Department of Feed and Animal Nutrition, Faculty of Animal Science, University of Sam Ratulangi, Manado, \\ Indonesia \\ ${ }^{4}$ Department of Biology, Faculty of Mathematics and Natural Sciences, University of Sam Ratulangi, Manado, \\ Indonesia \\ *Corresponding author email: rinileke@unsrat.ac.id
}

\begin{abstract}
The research aimed to determine the characteristics and quality of egg of commercial laying hens fed ration supplemented with garlic (Allium sativum) powder. The research used Completely Randomized Design (CRD) with five treatments and four replicates ( 5 hens each) for a total of 100 brown laying hens strain MB 402 . Garlic powder contained $24.62 \%$ crude protein, $38.81 \%$ fat, and $1.74 \%$ crude fiber. The treatments of garlic powder ration were $0,2,4,6$, and $8 \%$. The treatments performed were dietary, with R0 $=100 \%$ based diet $(B D) ; R 1=98 \%$ based diet $(B D)+2 \%$ garlic meal $(G M) ; R 2=96 \%$ based diet $(B D)+4 \% G M$, $R 3=94 \%$ based diet $(B D)+6 \% G M, R 4=92 \%$ based diet $(B D)+8 \% G M$. The study was conducted during eight (8) weeks. Collected data were quality, weight, shell weight, albumen weight and shell thickness of eggs. Data was analyzed with Analysis of Variance (ANOVA) and continued with Duncan's Multiple Range Test (DMRT). The results showed that $8 \%$ garlic powder ration increased weight and albumen weight of eggs. There were no significant effect of treatments in yolk weight, shell weight and shell thickness of eggs. Garlic powder supplementation on laying hen ration affected egg weight and albumen weight. The addition of garlic powder on laying hen ration of up to $4 \%$ increased egg weight. Albumen weight increased until garlic powder supplementation of up to $8 \%$. It is recommended the use of $8 \%$ garlic powder supplementation on lying hen ration without negative effects on egg quality.
\end{abstract}

Key words: dried garlic powder, egg layers, egg quality

Abstrak. Penelitian bertujuan untuk mengetahui karakteristik dari kualitas telur ayam yang diberi tepung bawang putih (Allium sativum) dalam ransum. Metode yang digunakan adalah Rancangan Acak Lengkap (RAL) dengan 5 perlakuan dan 4 ulangan, dan tiap perlakuan terdapat 5 ekor ayam petelur, sehingga materi yang digunakan adalah 100 ekor ayam petelur. Tepung bawang putih $24.62 \%$ protein, $38.81 \%$ lemak, dan $1.74 \%$ serat kasar. Perlakuan yang diberikan yaitu $0 \%, 2 \%, 4 \%, 6 \%$ dan $8 \%$ TBP. Perlakukuan penelitian terdiri atas ransum $\mathrm{RO}=100 \%$ ransum dasar; $\mathrm{R} 1=98 \%$ ransum dasar dan $2 \%$ bawang putih; $\mathrm{R} 2=96 \%$ ransum dasar dan $4 \%$ bawang putih; R3=94\% ransum dasar dan $6 \%$ bawang putih; R4=92\% ransum dasar dan $8 \%$ bawang putih. Penelitian dilakukan selama delapan minggu. Variabel penelitian: berat telur $(\mathrm{g})$, berat cangkang (g), berat albumen (g) dan ketebalan cangkang (g). Data dianalisis menggunakan analisis varian dan dilanjutkan dengan uji jarak berganda Duncan's. Hasil penelitian menunjukkan bahwa penggunaan tepung bawang putih sampai $8 \%$ dapat meningkatkan berat telur dan berat putih telur tetapi tidak memberikan pengaruh nyata terhadap berat kuning telur, berat kerabang dan tebal kerabang. Disimpulkan bahwa pemberian tepung bawang putih dapat meningkatkan bobot telur dan bobot albumen. Penambahan tepung bawang putih pada pakan ayam petelur hingga $4 \%$ dapat meningkatkan bobot telur. Bobot albumen meningkat hingga penambahan tepung bawang putih $8 \%$. Rekomendasi dari penelitian adalah penambahan tepung bawang putih dalam pakan hingga $8 \%$ dapat dilakukan tanpa menimbulkan pengaruh negatif pada kualitas telur.

Kata kunci: Tepung bawang putih, ayam petelur, kualitas telur

\section{Introduction}

White Leghorn (WLH) chickens are already well known for their ability to produce table eggs (An et al., 2010). Egg is one of the products of poultry known as source of high quality protein. In addition, egg has some benefits, such as high nutrition and affordable price, compared to other protein sources. 
Jein Rinny Leke et al./Animal Production. 21(2):98-103, 2019

Accredited by Kemenristek Dikti No 32a/E/KPT/2017. ISSN 1411-2027

Substantially, egg contains protein, fat, vitamin and mineral.

Egg quality is a general term that refers to several standards that determine both internal and external quality. External quality is focused on shell cleanliness, texture, shape, color, surface texture and egg integrity. Internal quality refers to egg white (albumen) cleanliness and viscosity, air cell size, yolk shape and strength. The decrease in internal quality can be determined by weighing the egg weight or watching the air cell and can also break down the eggs to check the condition of the yolk, egg white, albumen viscosity, yolk color and position, Haugh Unit (HU), and the presence or absence of blood spots (North and Bell, 1990)

Furthermore, the quality of egg itself can be seen from hygiene of egg shell, shape, and color. The egg weight of various poultries are varied. An egg weight consisted of $5.50 \mathrm{~g}$ shell, $0.25 \mathrm{~g}$ shell thickness, $37.00 \mathrm{~g}$ albumen, 17.30 g yolk, making a total weight of $54 \mathrm{~g}$. Structurally, internal yellow part of egg, or yolk, is covered by thin membrane, which is yolk egg's membrane (vitelline membrane). Whereas white part of egg is a heterogonoustransparent thick fluid, having rich protein. This part consists of $23 \%$ outer fluid, $57 \%$ of gelatin and $6-17 \%$ of inner fluid of total white egg, respectively. Other parts were in the form of chalaza, white egg and thin eggshell. Eggshell is formed in uterus, induced by estrogen. Quality of an egg will decrease if pores of eggshell become thinner due to evaporation. The balance between calcium and phosphor, located in womb, is required by egg layers to produce an egg and eggshell. As egg layers grow, the quality of egg starts to decrease. This is in accordance with the Abiola et al. (2008) recommending that during the development, egg layers experience three phases of production, i.e. small (41.09 - 50.97 g), medium (50.98 - $57.39 \mathrm{~g}$ ), large (57.40 $69.64 \mathrm{~g})$, and Rhone Island Red $57.20 \mathrm{~g}$
(Monira et al., 2003). For such development, total of feed given to egg layers was $110-120 \mathrm{~g}$ per day in average. Feed becomes the highest production cost in egg production. The best feed is any feed that can be digested and absorbed by egg layers' body. Egg production requires protein so that egg has a lot of protein. Egg layers need feed that have high protein content. In addition, they also need energy. An average balance of protein and energy required by egg layers in Indonesia comprises respectively of $16-17 \%$ and 2700 $\mathrm{kcal} / \mathrm{kg}$ of metabolic energy since Indonesia has warm climate.

The physical composition and egg characteristics are strongly influenced by the chicken breed and the feed given during the maintenance system (North and Bell., 1990). Both the quality and quantity of feed given determine the egg production and quality both internal and external. The feed determines internal and external quality according to age and maintenance management and it will be achieved efficiently if the nutrient content meets the chicken's needs.

The quality characteristics of the eggs include egg weight, white egg index, yolk index, albumen weight, yolk weight, and yolk color (Stadelman and Cotteriil, 1997; Monira et al. 2003; Parmer et al. 2006). The quality of egg itself is determined by egg's weight, white egg index, yolk index, white egg weight, yolk weight, and yolk color. Furthermore, the weight of egg is affected by feed nutrient content such as protein, fat, and amino acid, bexarotene, and flavonoid. One of efforts to fulfill protein and metabolic energy requirement is supplementing garlic (Allium sativum). Garlic is known as natural antibacterial. In Indonesia, garlic along with its leaves is used for natural antibiotics and as food plant. It contains anti-microbe substance, such as flavonoid and saponin. Flavonoid is a compound having phenol anti-microbe, used 
Jein Rinny Leke et al./Animal Production. 21(2):98-103, 2019

Accredited by Kemenristek Dikti No 32a/E/KPT/2017. ISSN 1411-2027

for disinfectant and bacteriostatic. When flavonoid works with denaturized protein, it forms complex compound into extracellular protein, inhibiting membrane integrity and covering cell until bacterial activity stops. Also, in garlic, bioactive playing role as antibacterial i.e. allicin, easily evaporated (volatile) in sulphur content. Garlic in feed has metabolic effect which decreases glucose, cholesterol and triglyceride in blood. Based on above description, the purpose of this research was to analyse the characteristics of egg quality of commercial laying hen fed with supplemented-dried garlic powder ration.

\section{Materials and Methods}

\section{Samples Preparation}

A sack of garlic, around $100 \mathrm{~kg}$, was bought from Bersehati Market, City of Manado. After that, garlic's peels were removed, sliced thinly, and dried under the sun for 3-4 days. Dried garlics, subsequently, was grinded until become powder. A number of $100 \mathrm{~kg}$ garlics became $35 \mathrm{~kg}$ dried garlic. The analysis of garlics was conducted in the Laboratory of Biochemistry, Nutrition and Poultry Food at Faculty of Animal Poultry, Universitas Gadjah Mada. The analysis revealed that dried garlic powder of $95.97 \%$ were $3.58 \%$ ashes, $24.62 \%$ crude protein, $38.81 \%$ fat, and $1.74 \%$ crude fiber. The results of amino acid analysis of garlic powder were lysine $0.97 \%$, isoluesin $0.67 \%$, phenilalanin $0.71 \%$, leucine $1.20 \%$, methionine $0.58 \%$. The phenolic content of garlic powder was $315.48 \mathrm{mg} / 100 \mathrm{~g}$. The vitamin A of garlic was $1.21 \mathrm{SI}$.

\section{Egg Layers, Diets and Experimental Design}

The research method used One-Way ANOVA Completely Randomized Design (CRD) Method, and ration used was one hundred MB 402 laying hens. The experiment was applied to five treatments and four replications. Then, each experiment was divided into five egg layers by using CRD method. In practice, materials used for this research were 42weeks MB 402 egg-laying hens. Feed used were $51 \%$ of corn, $10 \%$ of rice bran, $4 \%$ of $\mathrm{CaCO}_{3}$ and $35 \%$ of KLK 36 concentrate. The cage used was type of battery. Tools used were egg tray, digital scales (accuracy up to $0.001 \mathrm{gr}$ ) for scaling quality of egg, $30 \mathrm{~cm} \times 30$ $\mathrm{cm}$ of glass table, knife, calipers, yolk card for measuring color of yolk, paper tissue, and labels. The result of calculated composition and nutrient is, then, presented in Table 1.

The maintaining egg laying hens of MB 402 was started with feed adaption for 2 weeks. Then, it continued for 8 weeks. This activity included feeding every morning and noon, giving drink as ad libitium, sanitizing of feed and drink, and checking temperature and moisture with thermometer. Further, data interpretation was performed for 8 weeks and data collecting was executed once a week on third day. Measuring the quality of egg was performed in poultry (MB 402 laying hen) in the City of Manado. In addition, materials were eggs derived from pure bred egg laying hens of Medium Brown (MB 402) weighed 50 g.

Table.1. Chemical composition of the diets

\begin{tabular}{llllll}
\hline & \multicolumn{5}{c}{ Diets } \\
\cline { 2 - 6 } & R0 & R1 2\% & R2 4\% & R3 6\% & R4 8\% \\
\hline Crude protein (\%) & 17.44 & 17.54 & 17.63 & 17.72 & 17.82 \\
Fat (\%) & 6.78 & 6.71 & 6.65 & 6.59 & 6.52 \\
Crude fiber (\%) & 4.67 & 4.66 & 4.65 & 4.65 & 4.65 \\
Ca (\%) & 2.33 & 2.33 & 2.33 & 2.33 & 2.33 \\
P (\%) & 1.14 & 1.14 & 1.14 & 1.14 & 1.14 \\
ME (kcal/kg) & 2781.5 & 2783.88 & 2786.26 & 2788.65 & 2791.03 \\
\hline
\end{tabular}




\section{Research Activities}

Egg collection was carried out for one day. Eggs were taken from cage by random sampling method. The procedure to take egg samples was as follows: (1) numbered all cages; (2) made a lottery box and shuffled the lottery; (3) matched the number that came out with the number on the cage then placed the selected egg as a sample to the egg tray and repeated until all eggs in the egg tray sample were 50 eggs in each strain. Then, the eggs were evaluated for external and internal quality. Recording data was by weighing the egg (g/egg). The egg was cracked on a $30 \times 30$ $\mathrm{cm}$ glass.

All eggs were measured for internal quality. Egg were cracked then albumen was separated from the yolk. Then, egg was cleaned from the rest of albumen and finally weighed. Yolk weight (g/egg) was measured by first separating yolk from albumen, and then it was weighed. Albumen weight (g/egg) was calculated by subtracting egg weight by eggshell weight and yolk weight. Eggshell weight (g) was measured with digital scale. Eggshell thickness $(\mathrm{mm})$ was measured by digital caliper with accuracy of $0.001 \mathrm{~mm}$. The thickness of eggshell, diameter and height of the yolk were measured using digital caliper (Kucukyilmaz et al., 2012).

\section{Statistical Analysis}

The average data were analyzed with ANOVA. Analysis of data was done using oneway analysis of variance (one-way ANOVA) at significant level $(P \leq 0.01)$. Data analysis was continued with the Multiple Test Distance Duncan's Test (Steel and Torrie, 1994).

\section{Results and Discussion}

Data from observations and calculation of the average egg weight of each treatment during the study were listed in Table 2. The average egg weight for each treatment was from 59.00 up to $60.38 \mathrm{~g} / \mathrm{egg}$. These results were below 56.7 - $63.7 \mathrm{~g}$ for average egg weight of egg layers (USDA,2000). Data showed that adding $4 \%$ garlic increased egg weight. Furthermore, suplemented 6 - $8 \%$ garlic showed same results for egg weight. This showed that the quality of feed was largely determined by the content of protein and amino acids.

The content of protein and amino acids affected the egg weight. The size of the poultry eggs is strongly influenced by the protein content and essential amino acids in the feed (Latifah, 2007). Based on the analysis, garlic contains $24.62 \%$ protein. The amino acids contained in garlic affected the increase of egg weight of up to $4 \%$. At $6-8 \%$ of garlic flour,

Table 2. Effects of dried garlic feed on egg's quality of MB 402

\begin{tabular}{lccccc}
\hline & \multicolumn{5}{c}{ Treatments } \\
\cline { 2 - 5 } & $\mathrm{R} 0$ & $\mathrm{R} 1$ & $\mathrm{R} 2$ & $\mathrm{R} 3$ & $\mathrm{R} 4$ \\
\hline $\begin{array}{l}\text { Egg's weight } \\
\text { (g/egg) }\end{array}$ & $59.40 \pm 0.50^{\mathrm{a}}$ & $59.00 \pm 1.01^{\mathrm{a}}$ & $60.38 \pm 1.14^{\mathrm{b}}$ & $59.01 \pm 1.03^{\mathrm{a}}$ & $59.32 \pm 0.35^{\mathrm{a}}$ \\
$\begin{array}{l}\text { Yolk's weight } \\
\text { (g/egg) }\end{array}$ & $13.66 \pm 0.55$ & $13.59 \pm 0.51$ & $14.56 \pm 0.55$ & $14.06 \pm 0.40$ & $13.79 \pm 0.41$ \\
$\begin{array}{l}\text { Albumen's weight } \\
\text { (g/egg) }\end{array}$ & $34.64 \pm 1.54^{\mathrm{b}}$ & $34.54 \pm 1.06^{\mathrm{b}}$ & $33.32 \pm 1.08^{\mathrm{a}}$ & $34.10 \pm 1.04^{\mathrm{b}}$ & $35.13 \pm 1.2^{\mathrm{bc}}$ \\
$\begin{array}{l}\text { Eggshell's weight } \\
\text { (g/egg) }\end{array}$ & $5.07 \pm 0.05$ & $5.06 \pm 0.06$ & $5.09 \pm 0.06$ & $5.06 \pm 0.19$ & $5.09 \pm 0.06$ \\
$\begin{array}{l}\text { Eggshell's thickness } \\
\text { (mm) }\end{array}$ & $0.35 \pm 0.01$ & $0.35 \pm 0.01$ & $0.35 \pm 0.00$ & $0.35 \pm 0.00$ & $0.35 \pm 0.00$ \\
\hline
\end{tabular}

Notes: Various characteristics within each class indicated the presence of significant differences at the level of probability 
the egg weight was decreased due to the flavour and aroma of garlic flour which is not liked by egg layers.Fenwick dan Hanley (1985) stated that garlic flour contains active compound diallyl sulfide which is the most dominant component and very strong component in determining the flavour and aroma of garlic. Allicin (diallyl thiosulfinate) is one of the most active biological components contained in garlic. These component together with other sulfur components contained in garlic also play role in giving distinctive odor to garlic (Londhe, 2011).

The average weight of egg yolk for each treatment was between 13.59 up to 14.56 $\mathrm{g} / \mathrm{egg}$. These results were within the standard range of egg yolk weight. Leke et al. (2018) reported that the weights were $14.36-15.52$ g/egg. Tugiyanti et al. (2012) in the study of the usage of fermented fish meal of up to $8 \%$ reported that average egg weight of layers: 54.03-58.33 g/egg, egg yolk weight: 12.31 $13.39 \mathrm{~g} / \mathrm{egg}$, eggshell weight: $6.26-7.22 \mathrm{~g} / \mathrm{egg}$, egg index: $77.22-89.66$, hen day production: $41.67-63.06 \%$, shell strength: $52.13-59.13$ $\mathrm{mm}$, and HU: 70.41 - $77.34 \mathrm{~mm}$.

The result of supplementing garlic flour of up to $8 \%$ had no effect on egg yolk weight. This was because the layers had no differences in weight and age of adult sex, quality and feed consumption. Leeson and Summer (2001) stated that the weight of egg yolk was influenced by ovarian development, chicken weight, adult sex age, quality and quantity of feed and feed consumption.

The average weight of egg white (albumen) were $33.32-35.13 \mathrm{~g} / \mathrm{egg}$. The weight of egg white given $8 \%$ garlic flour were significantly different. This was caused by protein and amino acids in ration added with garlic flour. The high protein content of feed contributed to high protein in egg white. Amino acids consist of essential amino acids and non-essential amino acids, methionine including essential amino acids. Argo et al. (2013) reported that chickens given $0.1 \%$ methionine in $14 \%$ and $16 \%$ crude protein in ration had better egg quality and higher egg production.

Bell and Weaver., (2002) explained that egg white viscous layers contained proteins with gel characteristics related to the amount of ovomucin protein where viscous layers consist of inner and outer viscous layers. The inner viscous layer composes only $3 \%$ of total volume of egg white. King'ori (2012) explained that egg white was one part of a whole egg which has percentage of $58-60 \%$ of total weight of egg consisting of thick and thin layers.

The weight of egg white was influenced by density of albumen. The denser the albumen, the denser is the egg white. The elder the eggs used, the larger is the diameter of the egg white so that the index of the egg white is smaller. The change in egg white was caused by the exchange of gases between the outside air and inner egg through eggshell pores and water evaporation due to the duration of storage, temperature, humidity and porosity of eggshell (North and Bell, 1990).

The average weight of eggshell was 5.06 $5.09 \mathrm{~g} / \mathrm{egg}$. The average thickness of shell was $0.35 \mathrm{~mm}$. Maulin (2002) reported that average of marketed thickness and not easily broken of eggshells was $0.33-0.35 \mathrm{~mm}$. Shell thickness is positively correlated with weight. The thicker the shell, the heavier is shell and weight produced. The no difference results of adding garlic flour up to $8 \%$ was due to the no difference ratio of calcium and phosphorus in ration. Harmayanda et al. (2016) stated that the ability of animals to absorb and utilize calcium and phosphorus depends on the supply of vitamin $D$ in ration.

Adlan et al. (2012) stated that at the first egg-laying phase, the availability of vitamin $D$ and calcium was strongly needed. The low of calcium and vitamin $D$ intake at the beginning phase of eggs causes decrease in quality and quantity of eggs during peak production. Leeson and Summers (2001) stated that the 
main nutritional factors related to eggshell quality were calcium, phosphorus and vitamin D. The whole eggshells consisted of $98.5 \%$ calcium carbonate and $0.85 \%$ magnesium carbonate.

\section{Conclusions}

Garlic powder supplementation on laying hen ration affected egg weight and albumen weight. The addition of garlic powder on laying hen ration of up to $4 \%$ increased egg weight. Albumen weight increased until garlic powder supplementation of up to $8 \%$. It is recommended the use of $8 \%$ garlic powder supplementation on lying hen ration without negative effects on characteristics of egg quality.

\section{Acknowledgement}

Thank to the Government of the Republic of Indonesia through the Directorate General of Education (DGHE) who has funded Prominent Applied Research (Riset Terapan Unggulan Universitas (RTUU)) at Fiscal Year 2019 - 2020.

\section{References}

Abiola, S. S., O. O. Meeshioye, B. O. Oyerinde and M.A. Bamgbose. 2008. Effect Of Egg Size On Hatchability Of Broiler Chicks. Archieve Zootec, 57 (217): 83-86.

An, S. Y., Y. M. Guo, S. D. Ma, J. M. Yuan and G. Z. Liu. 2010. Effects Of Different Oil Source And Vitamin E In Breeder Diet On Egg Quality, Hatchability And Development Of The Neonatal Off Spring. Asian-Australian. Journal of Animal Science, 23 (2): 234-239.

Adlan, M., Y. Utomo, F. Afmy dan N. Fitriany. 2012. Laporan penelitian ternak unggas ayam petelur. Fakultas Peternakan Universitas Jenderal Sudirman.Purwokerto.

Argo, L., B. Tristiarti and I. Mangisah. 2013. Kualitas Fisik Telur Ayam Arab Petelur Fase I Dengan Berbagai Level Azolla Microphylla. Animal agriculture Journal, 2(1): 445-447.

Bell, D. D., W. D. Weaver and M. O. North, eds. 2002. Commercial Chicken Meat And Egg Production. Springer Science \& Business Media.

Fenwick, G. R., A. B. Hanley and J. R. Whitaker. 1985. The genus Allium-part 1. Critical Reviews in Food Science \& Nutrition. 22(3), 199-271.
Harmayanda, P., O. A. D. Rosidi and O. Sjofjan. 2016. Evaluasi Kualitas Telur Dan Hasil Pemberian Beberapa Jenis Pakan Komersial Ayam Petelur. Fakultas Peternakan. Universitas Brawijaya. Malang.

King'ori, A. M. 2012. Uses Of Poultry Egg; Egg Albumen And Egg Yolk. Journal Poultry Science, 5(2): 9-13.

Kucukyilmaz, K., M. Bozkurt, E. N. Herken, M. Cinar, A. U. Catli, E. Bintas and F. Coven. 2012. Effects Of Rearing Systems On Performance, Egg Characteristics And Immune Response In Two Layer Hen Genotype. Asian-Australian Journal of Animal Science, 25(4): 559-568.

Latifah, R. 2007. The increasing of afkir duck's egg quality with pregnant mare's serum gonadotropin (Pmsg) hormones. Jurnal Protein, 14. 1-8.

Leke, J. R., F. N. Sompie, E. Wantasen and T. E. Tallei. 2018. Nutrional characteristics and quality of eggs from laying hens fed on papaya peel meal diet. Jurnal Animal Production, 20 (3): 147154.

Leeson, S. and J. D. Summers. 2001. Commercial Poultry Nutrition. Thirth Edition. Departement of Animal and Poultry Science. Universirty of Guelph Ontariom. Canada.

Londhe, V., Gavasane, S. Nipate, D. Bandawane and P. Chaudhari. 2011. Role of garlic (Allium Sativum) in various disease: an overview. Journal Pharm Res Opin, 4 :129-134.

Maulin, J. M. 2002. Maintaining hatching egg quality. In D.D. Bell and D. Weaver (ed) Commercial chicken meat and egg production. $5^{\text {th }}$ Ed. Springer Science and Busines Media Inc. New York.

Monira, K. N., M. salahuddin and G. Miah. 2003. Effect of bread and holting period on egg quality characteristics of chicken. Journal of Poultry Science, 2(4): 261-263.

North, M. O. and D. D. Bell. 1990. Commercial chicken production manual. The $4^{\text {th }}$ Ed. Avi Publishing Company Inc. Westport, Connecticut.

Stadelman, W. J. and O. J. Cotteriil. 1977. Egg science and technology. The $2^{\text {nd }}$ Edition. The Avi Publ. Co. Inc.

Steel, R. G. D. and J. H. Torrie. 1994. Principles and procedures of statistics: a biometrical approach. McGraw-Hill Book Co.Inc. Pub. LTD. London.

Tugiyanti, E. and N. Iriyanti. 2012. Kualitas eksternal telur ayam petelur yang ransum dengan penambahan tepung ikan fermentasi menggunakan isolate produser antihistamin. Jurnal Aplikasi Teknologi Pakan, 1(2): 42-47.

United States Department of Agriculture (USDA). 2000. United states standart, Grade and weight classes for shell eggs. 